\title{
Correlation and path analysis in recombinant inbred lines (RILs) of wheat (Trticum aestivum L.)
}

\author{
Ramesh $^{1 *}$, Shailesh Marker ${ }^{2}$, S. Muniswamy ${ }^{1}$ and Yamanura ${ }^{1}$ \\ ${ }^{1}$ Agricultural Research Station, Aland Road, Kalburgi-585101 Karnataka, INDIA \\ ${ }^{2}$ Department of Genetics \& Plant Breeding, SHIATS, Allahabad-211007, Uttar Pradesh, INDIA \\ *Corresponding author. E-mail: ramesh4913@gmail.com \\ Received: August 11, 2015; Revised received: January 7, 2016; Accepted: May 20, 2016
}

\begin{abstract}
Correlation and path coefficient analysis were studied in 22 heat tolerant Recombinant Inbred Lines (RILs) of wheat. Analysis of variance revealed the significant difference among genotypes for all the characters. Suggested that there was ample scope for selection of promising RILs for yield improvement. A wide range of variability was exhibited by most of the traits. The results of correlation studies indicated that genotypic correlation coefficients were higher in magnitude than their corresponding phenotypic correlation coefficients for all the traits which indicated that association among these characters was under genetic control and indicating the preponderance of genetic variance in expression of characters. Grain yield per plant had high, significant and positive association with number of grains per spike, spike weight, spike length, canopy temperature depression, tillers per plant, grain filling period and chlorophyll content both at genotypic and phenotypic levels indicating that these traits were main yield attributing traits. Path analysis revealed that grains per spike, tillers per plant, spike length, had the highest positive direct effect on grain yield followed by flag leaf length, flag leaf width, days $50 \%$ heading, plant height, grain filling period, membrane stability and days to maturity at genotypic level. The selection of characters such as grains per spike, tillers per plant, spike length and spike weight would be helpful for further improvement in RILs of wheat.
\end{abstract}

Keywords: Correlation, Path analysis, Recombinant inbred line (RIL), Triticum aestivum, Wheat

\section{INTRODUCTION}

Cereals are the most important source of human food and nutrition (protein, minerals and vitamins) in Indian diet. Wheat (Triticum aestivum L.) is the second most important cereals in India after rice and improvement in the productivity has played a key role in making India self sufficient in the food production (Mahaptara et al., 2008).

The present study was conducted mainly on the Recombinant Inbred Lines (RILs) of wheat genotype which is common practice in plant breeding. It is achieved by self pollinating a line, while at the same time ensuring that another source of pollen does not let a cross-pollination occur. Through the use of back crossing and the use of marker assisted selection, this process has gotten significantly easier with a higher chance of success (Welsh and McMillan, 2012). The purpose of creating a RILs is that the progeny of the plants will generally produce the same offspring. The phenotypic traits as well as the genotypic traits should be nearly identical. Eventually, the RILs will start segregating for different traits, allowing for specific traits to be selected for further breeding programs (Shindo et al., 2002). Using this method, traits for disease resistance can be identified and incorporated into elite lines.

Grain yield is a sum total of the several component characters that together will give the overall yield in a crop. Grafius (1959) suggested that the selection for yield per se may not be effective as it is a function of the various component plant characters. Moreover, genes for yield per se may be absent but genes may be present for its components. Also, since all the characters are correlated, the change in one character brings about a series of changes in the other characters also. Therefore direct selection of characters correlated to yield may enable an indirect selection for higher yield. Thus to bring about a desirable change in yield or other character a proper understanding of the associations among the yield and yield contributing character is a must. This will help in selection of traits associated with highest expression of yield and simultaneously in improvement of one character without sacrificing much on the other character. If the association is positive it will accelerate the rate of genetic progress, while if the correlation is negative it will retard the genetic progress. The observed correlation is a function of linkage of genes determining the two characters. However it may also arise as a result of plieotropy and therefore it is the multiplicative interaction of yield and yield contributing characters that result in the ultimate 
yield. Hence, it becomes mandatory to have information on the association between different characters, and their relative contribution to the yield for developing a high yielding variety. Large spectrum genetic variability in segregating populations depends on the level of genetic diversity among genotypes offer better scope for selection, (Burton, 1952). Heritability estimates can anticipate improvement by selection of useful characters (Lush, 1949). The degree of association as revealed by correlation co-efficient is incomplete if the relative influence of the other characters to the calculated correlation co-efficient is not evaluated as sometimes even a significant correlation gives the more shadow of the influence of other correlated characters. Correlation studies permit only a measure of relationship between two traits in order to improve the yield potential without sacrificing the special quality features, (Snedecor and Cochran, 1967). On the other hand, path coefficient analysis has been found to give more specific information on the direct and indirect influence of each of the component characters upon grain yield. The main objective of this study is to investigate correlation co-efficient and path analysis in Recombinant Inbred Lines (RILs) under drought condition.

\section{MATERIALS AND METHODS}

The experiment was conducted with 22 Recombinant Inbred Lines (RILs) during Rabi 2013-14 at the field experimentation centre of the Department of Genetics and Plant Breeding, Sam Higginnbottom Institute of Agriculture Technology and Sciences, Allahabad. The experiment was laid out in randomized block design (RBD) with three replications. Standard agronomic practices and plant protection measures were adopted as per schedule. Three heat tolerant lines of wheat viz., K 9162, K 8962 and K9533 were taken as male parent and crossed with AAI-12. $F_{1}$ 's and $F_{2}$ 's were raised and evaluated but due to lack of desirable plant types in the $\mathrm{F}_{2}$ progenies, AAI-12 x K 9533 were discarded. Selection were made among the $\mathrm{F}_{2}$ progenies of AAI12 x K-9162 and AAI-12 x K-8962. Selection for cross derivatives based mainly on earliness, grain yield, number of tillers, spike length, spike weight, grains per spike and heat tolerant characters like canopy temperature depression and membrane stability and days to maturity. From the $\mathrm{F}_{3}$ generation and onwards, disruptive seasonal selection was practiced up to $\mathrm{F}_{6}$ generation among the early selected lines of the said cross derivatives. Crop was raised in two contrasting seasons that is in the normal season during Rabi (NovemberDecember to April-may) as winter crop and during off season (June-July to October) as summer wheat. Finally, 20 uniform RILs were developed. viz. RLW-1, RLW-2, RLW-3, RLW-4, RLW-5, RLW-6, RLW-7, RLW-8, RLW-9, RLW-10, RLW-11, RLW-12, RLW13, RLW-14, RLW-15, RLW-16, RLW-17, RLW-18, RLW-19, RLW-20, respectively. Observations were recorded on five randomly selected plants per lines for days to $50 \%$ heading, days to $50 \%$ flowering, flag leaf length, flag leaf width, plant height, number of tillers per plant, chlorophyll content, canopy temperature, membrane stability, spike length, days to maturity, grain filling period, weight per spike, grains per spike, test weight and grain yield/plant were recorded. The data were subjected to Burton statistics to measure the phenotypic coefficient of variation (PCV) and genotypic coefficient of variation (GCV). Heritability (h2) was worked out by using formula suggested by Lush (1949) and Burton and Devane (1953). The genetic advance in terms of the expected genetic gains was worked out by using the formula suggested by (Johnson et al. 1955). Simple correlation co-efficient computed to determine the association among all the yield contributing characters. The significance of correlation co-efficient (r) was tested by comparing

Table 1. Analysis of variance for different quantitative and physiological traits in RILs of wheat.

\begin{tabular}{|c|c|c|c|c|}
\hline \multirow[b]{2}{*}{ S. NO. } & \multirow[b]{2}{*}{ Characters } & \multicolumn{3}{|c|}{ Mean Sum of Squares } \\
\hline & & $\begin{array}{c}\text { Replications } \\
(\mathrm{df}=2)\end{array}$ & $\begin{array}{c}\text { Treatments } \\
(\mathrm{df}=\mathbf{2 1})\end{array}$ & $\begin{array}{c}\text { Error } \\
(\mathrm{df}=42)\end{array}$ \\
\hline 1 & Days to $50 \%$ Heading & 1.69 & $25.77 * *$ & 0.69 \\
\hline 2 & Days to $50 \%$ Flowering & 2.86 & $30.32 * *$ & 1.10 \\
\hline 3 & Flag Leaf Length & 0.59 & $46.03 * *$ & 4.02 \\
\hline 4 & Flag Leaf Width & 0.02 & $0.12 * *$ & 0.03 \\
\hline 5 & Plant Height & 7.46 & $31.88 * *$ & 6.17 \\
\hline 6 & Tillers/ Plant & 4.19 & $6.17 * *$ & 1.83 \\
\hline 7 & Spike Length & 0.02 & $1.42 * *$ & 0.38 \\
\hline 8 & Chlorophyll Content & 0.01 & $1.29 * *$ & 0.08 \\
\hline 9 & Membrane Stability & 2.49 & $173.78 * *$ & 9.87 \\
\hline 10 & Canopy Temperature Depression & 0.37 & $2.40 * *$ & 0.14 \\
\hline 11 & Days to Maturity & 0.56 & $48.04 * *$ & 2.05 \\
\hline 12 & Grain Filling Period & 3.31 & $24.02 * *$ & 1.17 \\
\hline 13 & Spike Weight/spike & 0.01 & $0.39 * *$ & 0.11 \\
\hline 14 & Grains/ Spike & 3.46 & $23.87 * *$ & 2.89 \\
\hline 15 & Yield/ Plant & 1.80 & $7.65 * *$ & 0.78 \\
\hline 16 & Test Weight & 0.13 & $22.75 * *$ & 2.17 \\
\hline
\end{tabular}

**Significant at $\mathrm{p}=0.01$ 
with 't' value at (n-2) degree of freedom (Snedecor and Cochran, 1967). The path coefficient analysis, a statistical device, which takes into account the cause and effect relation between the variables, is unique in partitioning the association into direct and indirect effect through other independent variables. The path coefficient analysis also measures the comparative significance of causal factors involved. This is simply a standardized partial regression analysis, wherein total correlation value is sub divided into causal scheme and path coefficient was worked out as method suggested by Al-Jibouri et al. (1958) and Dewey and Lu (1959), respectively.

\section{RESULTS AND DISCUSSION}

Analysis of variance revealed significant differences among the genotypes for all the characters. A wide range of variability was exhibited by most of the traits under study (Table 1). The significant difference among the genotypes for all the characters under study suggested that there was ample scope for selection of promising Recombinant Inbred Lines (RILs) for yield improvement. Similar finding was observed by Narjesi et al. (2010). On the basis of per se performance for grain yield per plant genotype RLW3, 7, 13, 5 and 15 were found promising as they showed high value for grain yield and its components. The highest variability (VP and VG) was recorded for membrane stability $(64.51,54.64)$ and plant height $(48.08,41.90)$ on an average. The higher magnitude of Genotypic coeffi- cient of variation (GCV) and Phenotypic coefficient of variation $(\mathrm{PCV})$ were recorded for canopy of temperature depressions, chlorophyll content, membrane stability suggesting sufficient variability and thus scope for genetic improvement through selecting for these traits. Relatively low magnitudinal difference was observed between GCV and PCV for all the traits studied. This indicated less environmental influence on the expression of all the attributes. Mukherjee et al. (2008) they also observed the PCV values higher than GCV values for different quantitative character in wheat.

The Heritability estimates coupled with expected genetic advance indicate the mode of gene action in the expression of traits, which helps in choosing an appropriate breeding methodology. High heritability along with moderate genetic advance was registered for plant height, grain filling period, grains per spike and test weight suggesting predominance of additive gene action in the expression of these traits. Therefore these characters can be improved by mass selection and other breeding methods based on progeny testing. Similar results were reported by Hanchinal et al. (1997) for spike length, number of grains per spike and yield per plant, Gupta and Verma (2000) for days to $50 \%$ flowering. Farzamipour et al (2013). Heritability estimates were high for 1000 grain weight, flag leaf length, and days to heading, grain yield, moderate genetic advance for most of the traits suggested the feasibility of selection among the RILs under investi-

Table 2. Estimates of genetic parameters for different quantitative and physiological traits in RILs of wheat.

\begin{tabular}{|c|c|c|c|c|c|c|c|c|c|c|c|}
\hline $\begin{array}{l}\text { S. } \\
\text { N. }\end{array}$ & Character & VG & VP & $\begin{array}{c}\text { GCV } \\
(\%)\end{array}$ & $\begin{array}{c}\text { PCV } \\
(\%)\end{array}$ & $\begin{array}{l}h^{2} b s \\
(\%)\end{array}$ & GA & $\begin{array}{c}\text { GA as } \\
\% \\
\text { mean } \\
\end{array}$ & $\begin{array}{c}\text { Range } \\
\text { Low- } \\
\text { est } \\
\end{array}$ & $\begin{array}{c}\text { Range } \\
\text { Highest }\end{array}$ & Mean \\
\hline 1 & $\begin{array}{c}\text { Days to } 50 \% \\
\text { Heading }\end{array}$ & 8.36 & 9.06 & 4.11 & 4.28 & 92 & 5.72 & 8.14 & 65.67 & 75.33 & 70.30 \\
\hline 2 & $\begin{array}{l}\text { Days to } 50 \% \\
\text { flowering }\end{array}$ & 9.74 & 10.84 & 4.16 & 4.39 & 90 & 6.09 & 8.13 & 70.00 & 81.00 & 74.95 \\
\hline 3 & Flag Leaf Length & 14.00 & 18.03 & 12.27 & 13.93 & 78 & 6.79 & 22.28 & 23.94 & 38.43 & 30.49 \\
\hline 4 & Flag Leaf Width & 0.03 & 0.06 & 10.01 & 14.09 & 50 & 0.26 & 14.63 & 1.30 & 2.14 & 1.75 \\
\hline 5 & Plant Height & 41.90 & 48.08 & 6.76 & 7.24 & 87 & 12.45 & 13.00 & 85.73 & 105.83 & 95.80 \\
\hline 6 & No. Tillers/ Plant & 1.45 & 3.28 & 12.18 & 18.33 & 44 & 1.65 & 16.67 & 5.33 & 12.62 & 9.88 \\
\hline 7 & Spike Length & 0.34 & 0.73 & 5.43 & 7.92 & 47 & 0.83 & 7.67 & 9.95 & 12.62 & 10.82 \\
\hline 8 & $\begin{array}{c}\text { Chlorophyll Con- } \\
\text { tent }\end{array}$ & 0.40 & 0.49 & 22.02 & 24.33 & 82 & 1.18 & 41.08 & 1.65 & 4.05 & 2.88 \\
\hline 9 & $\begin{array}{l}\text { Membrane Stabil- } \\
\text { ity }\end{array}$ & 54.64 & 64.51 & 18.69 & 20.31 & 85 & 14.01 & 35.43 & 25.58 & 51.05 & 39.55 \\
\hline 10 & $\begin{array}{l}\text { Canopy Tempera- } \\
\text { ture Depression }\end{array}$ & 0.75 & 0.90 & 27.83 & 30.47 & 83 & 1.63 & 52.35 & 2.05 & 5.18 & 3.12 \\
\hline 11 & Days to Maturity & 15.33 & 17.38 & 3.55 & 3.78 & 88 & 7.57 & 6.86 & 105.00 & 121.00 & 110.44 \\
\hline 12 & $\begin{array}{l}\text { Grain Filling Pe- } \\
\text { riod }\end{array}$ & 7.62 & 8.79 & 7.77 & 8.35 & 87 & 5.29 & 14.91 & 31.00 & 42.00 & 35.50 \\
\hline 13 & $\begin{array}{l}\text { Spike Weight/ } \\
\text { spike }\end{array}$ & 0.09 & 0.21 & 13.05 & 19.78 & 43 & 0.41 & 17.72 & 1.73 & 3.03 & 2.32 \\
\hline 14 & Grains/ Spike & 6.99 & 9.89 & 6.96 & 8.28 & 71 & 4.58 & 12.06 & 34.00 & 44.00 & 37.97 \\
\hline 15 & Grain yield/ Plant & 2.29 & 3.07 & 11.72 & 13.57 & 75 & 2.69 & 20.85 & 10.79 & 15.96 & 12.92 \\
\hline 16 & Test Weight & 6.86 & 9.03 & 7.45 & 8.55 & 76 & 4.70 & 13.38 & 31.36 & 40.83 & 35.14 \\
\hline
\end{tabular}

$\mathrm{VP}=$ Phenotypic variance $; \mathrm{VG}=$ Genotypic variance; $\mathrm{GCV}=$ Genotypic coefficient of variation; $\mathrm{h}^{2}=$ Heritability; $\mathrm{PCV}=\mathrm{Pheno-}$ typic coefficient of variation; $\mathrm{GA}=$ Genetic advance 


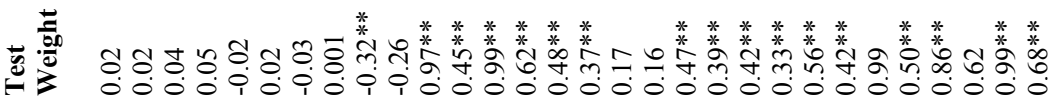

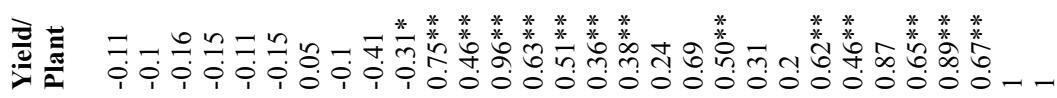

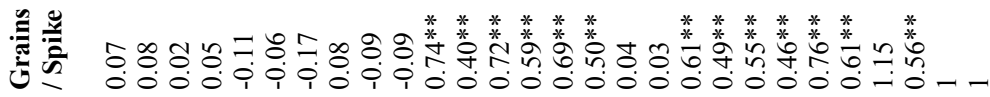

䓂喜

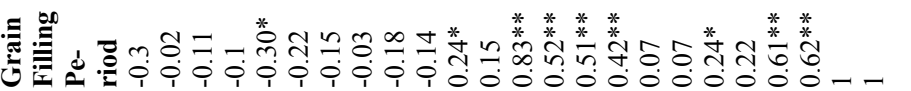

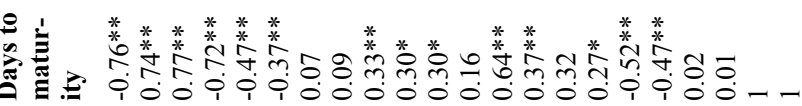

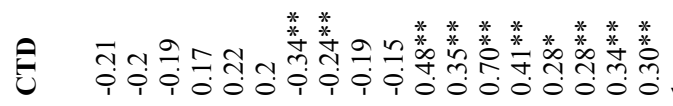

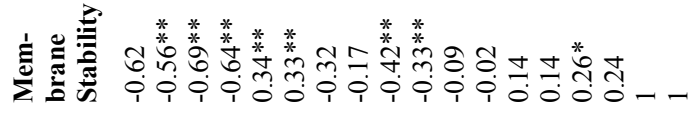

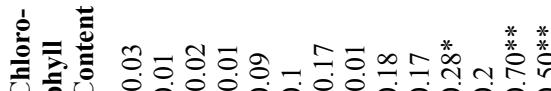

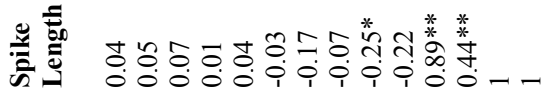

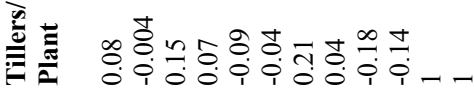

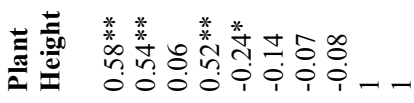

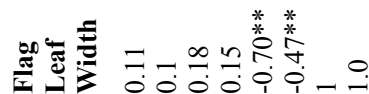

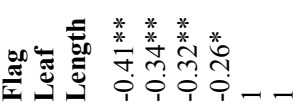

$2 \stackrel{\infty}{=0}$

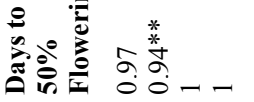

$\stackrel{3}{\circ}$

2.

ลิํํำ

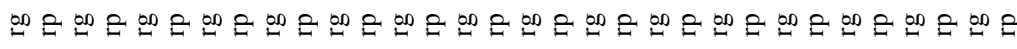

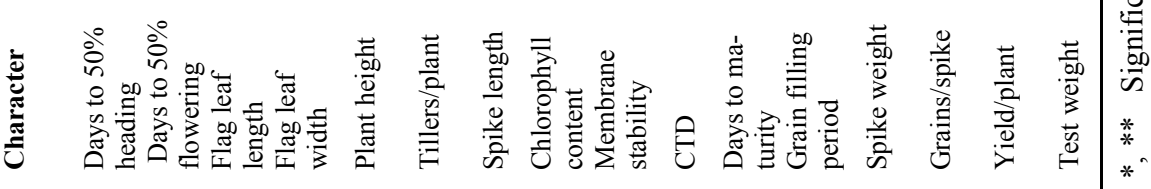




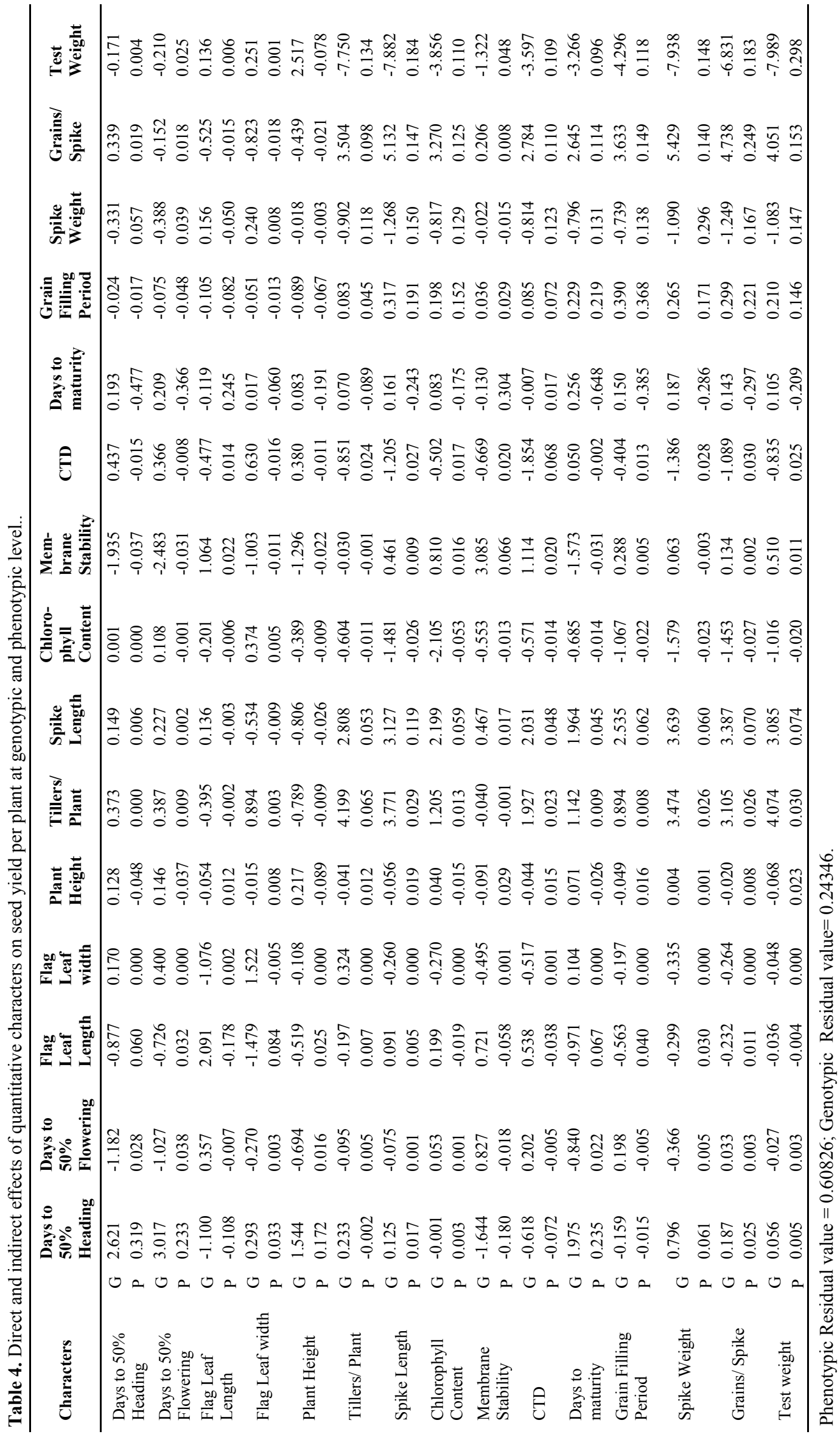


gation. However, character like days to $50 \%$ heading, days to $50 \%$ flowering and days to maturity. Possessed high ranged heritability with low genetic advance, suggesting non-additive gene action. The high heritability of these traits was due to favourable influence of environment rather than genotypic and selection for these traits may not be rewarding similar results were reported by Panwar, B. S. and Singh, D. (2000) for flag leaf area, grain yield, spike length and harvest index in wheat. Whereas, characters like canopy temperature depression, chlorophyll content, membrane stability, flag leaf length and yield per plant possessed high heritability with high genetic advance. Johnson et al. (1955) showed that high heritability should be accompanied by high genetic advance to arrive at more reliable conclusion. The breeder should cautious in making selection based on heritability as it includes both additive and non-additive gene effect.

Estimates of phenotypic and genotypic correlation coefficients between each pair of characters. The results showed that, in general, the genotypic correlation coefficients (rg) were higher than the phenotypic correlation coefficients (rp) which indicated that association among these characters was under genetic control and indicating the preponderance of genetic variance in expression of characters. It might be due to depressing effect of environment on character association as reported earlier for wheat crop (Ahmad et al., 2003; Paroda and Joshi, 1970). In the present investigation the genotypic and phenotypic correlation coefficient of different character with grain yield per plant and their relationship among themselves are presented in Table 3. It was found that the grain yield per plant showed positive significant correlation with number of grains per spike $(\mathrm{rg}=0.89$ and $\mathrm{rp}=0.67)$, spike weight $(\mathrm{rg}=0.87$ and $\mathrm{rp}=0.65)$, spike length ( $\mathrm{rg}=0.96$ and $\mathrm{rp}=0.63)$, canopy temperature depression $(0.50)$, number of tillers per plant ( $\mathrm{rg}=0.75$ and $\mathrm{rp}=0.46)$, grain filling period $(\mathrm{rg}=0.62$ and $\mathrm{rp}=0.46)$ and chlorophyll content ( $\mathrm{rg}=0.51$ and $\mathrm{rp}=0.36$ ) at both genotypic and phenotypic levels, which indicates strong association with these character with yield. Therefore, by increasing the value of these components traits, yield may easily pushed up suggesting the selection for these characters will be useful in improving seed yield. These results are in agreement with the work of Ajmal et al. (2009), Khan et al. (2010) Zafarnaderi et al. (2013). The correlation showed negative significant association with plant height $(-0.31 * *)$ at phenotypic level, negative and significant association indicates that selection on the basis of these characters will not be beneficial as increase in one character will decrease the other. While the positive but non-significant correlation was observed with membrane stability $(\mathrm{rg}=0.69$ and $\mathrm{rp}=0.24)$ and days to maturity ( $\mathrm{rg}=0.31$ and $\mathrm{rp}=0.20$ ) both at genotypic and phenotypic levels and the correlation showed negative non- significant association days to $50 \%$ heading ( $\mathrm{rg}=-0.11$ and $\mathrm{rp}=-0.10)$, flag leaf length ( $\mathrm{rg}=-0.11$ and $\mathrm{rp}=-0.15)$ and days to $50 \%$ flowering ( $\mathrm{rg}=-0.16$ and $\mathrm{rp}=-0.15$ ) with grain yield per plant both at genotypic and phenotypic levels. Test weight showed positive significant association with grain yield per plant $(\mathrm{rg}=0.99$ and $\mathrm{rp}=0.68$ ), grains per spike ( $\mathrm{rg}=0.86$ and $\mathrm{rp}=0.62$ ), spike length $(\mathrm{rg}=0.99 \mathrm{rp}=0.62)$, number of tillers per plant ( $\mathrm{rg}=0.97$ and $\mathrm{rp}=0.45$ ) both genotypic and phenotypic levels. The path coefficient analysis, a statistical device developed by Wright (1921), which takes into account the cause and effect relation between the variables is unique in partitioning the association into direct and indirect effect through other independent variables.

The path coefficient analysis also measures the comparative significance of causal factors involved. This is simply a standardized partial regression analysis, wherein total correlation value is sub divided into causal scheme. In the present study results of genotypic and phenotypic path coefficient analysis sixteen quantitative and physiological characters are presented in (Table 4). Path coefficient analysis displayed that maximum positive direct effect on grain yield plot were mostly by grains per spike (4.738), tillers per plant (4.199), grain filling period (3.085), spike length (3.127), flag leaf length (2.091), flag leaf width (1.522), days to $50 \%$ heading (2.621), plant height (0.217) and days to maturity (0.256) had highest positive and direct effect on seed yield at genotypic level. While days to $50 \%$ flowering $(-1.029)$, chlorophyll content (-2.105), canopy temperature depression $(-1.854)$, spike weight $(-1.09)$ and test weight $(-7.89)$ had negative direct effect on seed yield at genotypic level. Similar trend of positive direct effect on seed yield was observed at phenotypic level for days to $50 \%$ heading (0.319), grain filling period (0.296), grains per spike $(0.249)$, test weight $(0.298)$, days to $50 \%$ flowering (0.038), and tillers per plant (0.065), membrane stability (0.066) and canopy temperature depression (0.068). Similar results were reported by Bhushan et al. (2013) observed highest contribution towards grain yield with test weight, tillers per plant per plant, spike length and grains per spike. Therefore, these characters should be considered as main components for selection in a breeding program for higher grain yield. While the character leaf length $(-0.178)$, flag leaf width (-0.005), plant height (-0.089), chlorophyll content $(-0.053)$ and days to maturity $(-0.089)$ had negative direct effect on seed yield at phenotypic level. It was also observed that the highest negative direct effect was exerted by Rangare et al. (2010) and Bhushan et al. (2013) reported that day to heading and plant height has direct but negative effects on grain yield. In plant breeding, it is very difficult to have complete knowledge of all component traits of yield. The residual effect permits precise explanation about the pattern of interaction of other possible components of yield. In other words, residual effect measures the role of other possible independent variables not included in the study on the dependant variable. Rela- 
tively low, positive residual values of $\mathrm{R}=0.243$ and 0.608 was observed at genotypic and phenotypic level respectively. It indicates the less unexplained variation and characters included in the present study accounted for most of the variation. The results are in agreement with Thanki and Sawargaonkar (2010).

\section{Conclusion}

On the basis of results as summarized above, it is concluded that the great deal of variability for the important characters studied even in highly selected lines under the present investigation. Some RILs like RLW-3 RLW-7, RLW-13, RLW-5 and RLW-15 showed promising performance; therefore they may be useful for constitution of new temperature tolerant wheat variety. Spike length, spike weight, number of tillers per plant, grains per spike, grain filling period and test weight were the prime yield contributing characters. These characters are significantly and positively correlated with yield, therefore their direct selection would be effective in yield improvement in wheat. Path analysis revealed that grains per spike, tillers per plant, spike length, flag leaf length, flag leaf width, days $50 \%$ heading, plant height and grain filling period had the highest positive direct effect on grain yield emphasis should be given in selection of such characters for further improvement in RILs of wheat.

\section{REFERENCES}

Ahmad, M., F. Mohammed, K. Maqbool, A. Azamand and S. Iqbal. (2003). Genetic variability and traits correlation in wheat. Sarhad J. Agric., 19(3): 347-351.

Ajmal, S., Zakir, N. and Mujahid, M.Y. (2009). Estimation of genetic parameters and character association in wheat. J. Agric and Biol. Sci., 1(1):15-18.

Al-Jibouri, H.A., Miller, A.R. and Robinson, H.F. (1958). Genotypic and environmental variances and co-variances in upland cotton crosses of interspecific origin. Agron. J., 50: 633-637.

Bhushan, B., Bharti, S., Ojha, A., Pandey, M., Gourav, S.S., Tyagi, B.S. and Singh, G. (2013). Genetic variability, correlation coefficient and path analysis of some quantitative traits in bread wheat. $J$. Wheat Res., 5(1): 21-26.

Burton and Devane (1953). Estimating heritability all rescues from replicated clonal material. J. Agron., 45: 474-481.

Burton, G.W. (1952). Quantitative inheritance of grasses. Proc. $6^{\text {th }}$ International Grassland congress, 1:277-283.

Dewey, D.R. and Lu, K.H. (1959). A correlation and path coefficient analysis of components of wheat grass seed production. Agron. J., 51: 515-518.
Farzamipour, R., Moghaddam, M., Aharizad, S. and Rashidi. (2013). Genetic variation for agronomic characters and drought tolerance among the recombinant inbred lines of wheat from the Norstar $x$ Zagross cross, Intenational J. Biosci., 3(8):76-86.

Grafius, J.S. (1959). Hetrosis in barley. J. Agron., 51:551554.

Gupta, S.K. and Verma, S.R. ( 2000). Variability, heritability and genetic advance under normal and rainfed condition in durum wheat (Triticum durum DESF) Indian. J. Agric. Res., 34(2): 122-125.

Johnson, H.W., Robison, H.F. and Comstock, R.E. (1955). Estimates of genetic and environmental variability in wheat. Agronomy Journal, 47: 314-318.

Hanchinal, R.R., Maled, B.G., Naiak, V.R. and Patil, B.N. (1997). Genetic variability and heritability in emmer wheat. Journal of Maharashtra Agricultural Universities, 22(1): 88-90.

Khan, A.J., Azam, F. and Ali, A. (2010). Relationship of morphological traits and grain yield in recombinant inbred wheat lines grown under drought conditions. Pakistan Journal of Botany, 42(1):259-267.

Lush, J.L. (1949). Heritability of quantitative traits in farm animals. Proceeding of $8^{\text {th }}$ international congress genetic Heridos (supplementary), 336-357.

Mahaptara, R.N., Yadava, M.S. and Mohan, K.S. (2008). Genetic variation, character association in rainfed wheat. Indian Journal of Dryland Agricultural Research and Development, 18(2): 196-198.

Mukherjee, Subhra., Gupta, Suparna. and Bhowmik, N. (2008). Genetic variability of important quantitative characters in modern wheat (Triticum aestivum L.) cultivars in Tarai Region of West Bengal. Environ and Ecol, 26 (2): 683-686.

Narjesi, V., Hervan, E.M., Zali, A.A., Mardi, M. and Naghavi, M.R. (2010). Effect of salinity stress on grain yield and plant characteristics in bread wheat recombinant inbred lines. Iranian J. Crop Sci. 12(3):291-304

Paroda, R.S. and Joshi, A.B. (1970). Correlation, path coefficient and their implication in discriminant function for selection in wheat (Triticum aestivum L.). Heredity 25: 383-392.

Panwar, B.S. and Singh, D. (2000). Genetic variability and correlation studies in wheat (Triticum aestivum L.). Indian Journal of Plant Genetic Resources. 13(3): 286289.

Rangare, N.R., Krupakar, A., Kumar, A. and Singh, S. (2010). Character association and component analysis in wheat. Electron. J. Plant Breed., 1(3): 231-238.

Shindo, D., Mingeot, J.M. and Jacquemin. (2002). Quantitative trait loci for resistance against Yellow rust in two wheat-derived recombinant inbred line populations. Theory of Applied Genetics. 104:111-118.

Thanki, H.P. Sawargaonkar, S.L. and Hudge, B.V. (2010). 